\title{
CHICKEN À LA FRONTO
}

\section{Olga V. Budaragina}

St. Petersburg State University,

7-9, Universitetskaya nab., St. Petersburg, 199034, Russian Federation; o.budaragina@spbu.ru

Bibliotheca classica Petropolitana,

9/6, Malyi pr. P.S., St. Petersburg, 197198, Russian Federation; o.budaragina@spbu.ru

This article discusses possible eponyms of the dish pullus Frontonianus in the cookbook "De re coquinaria" (Apic. 6, 8, 12). The attribution faces a number of difficulties, such as the authorship and dating of the corpus ascribed to Apicius and the fact that the cognomen Fronto did not belong to one particular nomen gentilicium. The author considers several Frontones: the addressee of Martial's epigram (I, 55, 2 ), a rich patron mentioned in Juvenal's satire $(1,12)$, and a person who wrote on agriculture and was a contemporary of the emperor Septimius Severus. A special section is dedicated to M. Cornelius, the teacher of Marcus Aurelius and the most famous among Frontones. The article studies both external evidence and the internal logic of the correspondence of M Cornelius Fronto in order to find out his attitude to food and to consider the possibility that the dish was named after him. The author concludes that there are no compelling arguments to attribute pullus Frontonianus with certainty to any of the Frontones discussed.

Keywords: M. Cornelius Fronto, pullus Frontonianus, chicken à la Fronto, Apicius, food in antiquity, Marcus Aurelius, Seneca the Younger.

The ancient cookbook "De re coquinaria" ascribed to Apicius mentions pullus Frontonianus among fifteen other chicken recipes:

Pullum Frontonianum ${ }^{1}$ : pullum praedura, condies liquamine ${ }^{2}$, oleo mixto, cui mittis fasciculum anethi, porri, satureiae et coriandri viridis, et coques. ubi coctus fuerit, levabis eum, in lance defrito perungues, piper aspargis et inferes (Apic. 6, 8, 12) ${ }^{3}$.

'Frontonian chicken: sear the outside of the chicken, flavour with a mixture of liquamen and oil, to which you add a bundle of dill, leek, savory and green coriander and cook it. When it is cooked, lift it out, drizzle defritum over it on the serving dish, sprinkle with pepper and serve'4.

This recipe neither mentions anything as exotic as ostrich ${ }^{5}$ nor includes any refined ingredients. One can say that the only distinctive feature of pullus Frontonianus is a recommendation to fry the chicken on both sides before further cooking (this probably might help to preserve its succulence). The purpose of the present paper is not to go into further discussion of the recipe as such but to look at the possibilities of its attribution and the difficulties that arise in this connection.

Recipes referring to people are not numerous in the "De re coquinaria": for 468 entries, there are just twenty-two recipes of this kind ${ }^{6}$. All eponyms occur once, except for Apicius himself who receives seven records ${ }^{7}$ and the emperor Vitellius with three entries ${ }^{8}$.

1 The title as often in Apicius takes the accusative because the verb coques is assumed.

2 Apicius prefers the term liquamen (used 391 times) vs. garum (occurs only in 7, 13, 1).

3 The numeration follows that of the edition: Milham 1969.

${ }^{4}$ Grocock, Grainger 2006, 233.

5 Also in Apicius $(6,1,1-2)$.

${ }^{6}$ For the full list see: Edwards 2001, 261-262. He omits porcellum Vitellianum though $(8,7,7)$.

$74,1,2 ; 2,14 ; 3,3 ; 5,4,1 ; 6,7 ; 7,4,2 ; 8,7,6$.

$85,3,5 ; 5,3,9 ; 8,7,7$.

(c) St. Petersburg State University, 2016 
At the same time, only three titles can be safely attributed to specific people. All of them are emperors: the above-mentioned Vitellius $(5,3,9)$, famous for his gluttony (Suet. Vit. 13), Trajan $(8,7,16)$, and Commodus $(5,4,4)$. As we shall see, scholarly tradition has treated the recipes named after people in different ways, giving examples of both philological temerity ${ }^{9}$ and caution ${ }^{10}$.

Let us first look at some textual issues concerning our passage. Frontonianum is the reading of the two best manuscripts of the "De re coquinaria" - codex $\mathrm{V}^{11}$ and codex $\mathrm{E}^{12}$, in which manus secunda corrects a nonsensical frotitonianum. This clear textual transmission does not seem to need debate; nevertheless, it has become a matter of dispute because of the title of another recipe from the section "Pork" - Frontinianum porcellum ('suckling pig à la Frontinus' $-8,7,10$ ), which in a number of fifteenth century manuscripts is also called frontonianum ${ }^{13}$. This led to the fact that some editors of Apicius have decided to unify two strands. On the one hand, J. D. Vehling ${ }^{14}$ reads Frontinianum porcellum, but, for some reason, he translates both this and pullus Frontonianus - à la Fronto'. On the other, R. Maier hesitates between Fronto and Frontinus in the chicken recipe and proposes a conjecture front[on]ianum, ${ }^{15}$ which seems to me rather unlikely; moreover, it does not save the day. As a possible basis for his argument, the scholar points out "die starke Ähnlichkeit" 16 of the two recipes and argues that this is a reason to attribute them to one person:

Frontinianum porcellum: exossas, praeduras, ornas. adicies in caccabum liquamen, vinum, obligas fasciculum porri, anethi, media coctura mittes defritum. coctum levas et siccum mittes. piper asparges et inferes ${ }^{17}(8,7,10)$.

'Suckling pig à la Fronto: bone the pig, parboil, garnish in a saucepan. Add broth, wine, bind. When half done, add a bunch of leeks and dill, some reduced must. When cooked wipe the pig clean, let it drip off; sprinkle with pepper, serve' ${ }^{18}$.

In my view, "close resemblance" can be observed only in the pre-frying of the chicken and suckling pig (praedura). However, this cooking method is quite typical of other pork recipes ${ }^{19}$. As to the use of liquamen, defritum, dill, leek, and pepper, they are too often mentioned in the "De re coquinaria" in various combinations to make the recipes look similar. Thus, I will accept the reading of the two best Apicius' manuscripts and will consider pullus Frontonianus and porcellum Frontinianum as dishes referring to two different people.

It must be admitted that attempts to identify the Fronto to whom the chicken recipe is dedicatedface a number of obvious difficulties. The first one has to do with the authorship

${ }^{9}$ Edwards 2001, 257; 261-262.

${ }^{10}$ André 1965, passim.

11 Codex Vaticanus Urbinas Latinus 1149, saec. IX.

${ }^{12}$ Codex New York Academy of Medicine 1, saec. IX.

$13 \mathrm{~T}$ (codex Vaticanus Urbinas Latinus 1145), C (codex Riccardianus), and P (codex Parisinus Latinus 8209).

14 Vehling 1936, 153, 196.

15 Maier 1991, 97.

16 Maier 1991, 197-198.

17 Underlining is mine - OB.

18 Vehling 1936, 196.

19 E.g. $8,7,1 ; 9 ; 10$ etc. 
and dating of the corpus ascribed to Apicius. It is not our task to get deeper into this question $^{20}$, but traditionally ${ }^{21}$ the recipe collection is associated with the name of the famous rich man and gourmet M. Gavius Apicius who was a contemporary of the emperor Tiberius and who is mentioned by Seneca (Ad Helv. 10, 8-9), Pliny the Elder (NH 10, 68), Martial (3, $22)$, Athenaeus (1,12 - Kaibel), etc. The latter talks also about another Apicius ${ }^{22}$ who lived in the time of Trajan and sent oysters preserved in a special way to him in Parthia (far away from the sea!) (1,13 - Kaibel). P. Faas rightly assumes that this might indicate the fact that by this time Apicius had already become a nickname ${ }^{23}$. This tendency might be illustrated by a later example from Tertullian who states that all grammarians are called after Aristarchus, and cooks after Apicius (Apol. 1, 6). At the same time, it does not really matter for our discussion how one should date Apicius (or Apicii) because the text of the cookbook, which became famous under his name, is not the work of one author "but rather a haphazard collection assembled over many centuries" 24 . The language of the "De re coquinaria" as well as the recipes themselves combine elements of earlier and later layers (right up to the fourth century) ${ }^{25}$, which means that Fronto who was the eponym of pullus Frontonianus theoretically could have lived at any time between the first and fourth centuries.

The second difficulty with identifying an individual concerns the fact that cognomen Fronto (cf. English "Forehead" or Russian "Lobanov") was quite widespread and did not belong to one particular nomen gentilicium ${ }^{26}$. This situation is different from that of other recipes referring to people, such as "beef Stroganov", which is related to a large and important Russian family ${ }^{27}$, or "sandwich", which is associated with a certain representative of the Sandwich $\operatorname{clan}^{28}$.

One should say that a number of attempts have been made to find out who Fronto of the chicken recipe was. The answers vary: some scholars point to possible candidates, while others declare such attempts vain and fruitless ${ }^{29}$. Let us look at two hypotheses put forward by a German scholar Chr. T. Schuch who managed an edition of the "De re coquinaria" in the mid-nineteenth century ${ }^{30}$. His first hypothesis is that this could have been the same Fronto mentioned by Martial and Juvenal. An epigram by Martial appeals to a noble man with whom the poet shares his longing for living close to nature. The addressee, who seems to be a man of distinction, is called clarum militiae, Fronto, togaeque decus $(1,55,2)$ :

Vota tui breviter si vis cognoscere Marci,

Clarum militiae, Fronto, togaeque decus,

Hoc petit, esse sui nec magni ruris arator $\langle\ldots>(1,55,1-3)$.

\footnotetext{
${ }^{20}$ For the latest discussion see, for example: Grigor'eva 2000, $3 \mathrm{ff}$.; Grocock, Grainger 2006, $13 \mathrm{ff}$.

21 This can hardly be true. For the description of the manuscript tradition and author's name, see: Vollmer 1920, 5 ff.; Vehling 1936, 19-20.

22 Edwards $(2010,261)$ believes this Apicius to be the author of the "De re coquinaria".

${ }^{23}$ Faas 2003. Available at: https://books.google.ru (accessed: 03.05.2016).

${ }^{24}$ Grocock, Grainger 2006, 13.

25 Fuhrmann 1974, 1, 984; Grigor'eva 2000, 3.

${ }^{26}$ We know of more than twenty remarkable representatives of different families who bore this cognomen (Groag 1910, 13, 111-112).

27 Sometimes it is even attributed directly to the count Alexander Grigor'evich Stroganov (1795-1891).

${ }^{28}$ Namely, John Montagu, $4^{\text {th }}$ Earl of Sandwich (1718-1792).

29 André 1965, 186.

${ }^{30}$ Schuch 1867,129 . This edition appeared ten years after his death.
} 
At the beginning of the first satire, Juvenal expresses his indignation at senseless recitations performed in Rome under the plane trees of a certain Fronto (Frontonis platani $-1,12)$. Here the poet talks about a rich patron who lent out his grounds for poetry recitations. It must be admitted that the identity of Fronto ${ }^{31}$ (or two different Frontones) mentioned by these authors is also a matter of dispute. Some scholars prefer to avoid making any decision concerning the personality of the man in question ${ }^{32}$. Others, such as L. Friedlaender ${ }^{33}$, discuss several possibilities but do not reach a definite conclusion. Mainly, two names are referred to in connection with the topic. The first one is T.Catius Caesius Fronto ${ }^{34}$, suffect consul in 96 and a famous orator who was capable, according to Pliny, of bringing tears to the eyes of many (vir lacrimarum movendarum peritissimus Epist. 2, 11,3). We also know that he was a relative of the epic poet Silius Italicus ${ }^{35}$. The second possible candidate discussed is his contemporary Q. Pactumeius Fronto, suffect consul in $80^{36}$. As was said above, the commentators are cautious about making their decisions and one cannot be sure that Martial and Juvenal are talking about the same person ${ }^{37}$. It is important for us at the moment that Chr. T.Schuch's proposal to identify Fronto in Apicius with the heroes of Martial and Juvenal (whoever they were) did not gain support with later editors of the "De re coquinaria". It seems to me that the only argument pro could be the fame and wealth of these people.

Chr. T. Schuch's second hypothesis puts forward as a possible eponym of chicken à la Fronto a person who lived in the time of the emperor Septimius Severus and wrote on agriculture. His works are not preserved except for several quotations in the Byzantine treatise "Geoponika", which was compiled during the reign of Constantine VII Porphyrogennetos in the tenth century ${ }^{38}$. A number of scholars of Apicius have supported this point of view ${ }^{39}$, but I tend to agree with J. André who remarks that knowledge of agriculture does not imply per se an interest in gastronomy ${ }^{40}$.

Now I shall discuss one more possible eponym of Apicius' pullus Frontonianus. I am talking about the most famous among Frontones - M. Cornelius, who was the leading figure of Roman letters of the mid second century and was considered to be the best orator of his time ${ }^{41}$ and "non second, but a twin ornament/glory of Roman oratory"42 (obviously, in comparison to Cicero). Because his correspondence with the members of the Antonine dynasty has been preserved, Fronto is better known today as a teacher of Latin rhetoric to the two adoptive sons of the emperor Antoninus Pius - Marcus Aurelius and his younger

${ }^{31} \mathrm{Chr}$. Schuch believes that Fronto of Martial and Juvenal is the same person (Schuch Ibid.). The same opinion was later expressed by S. Morton Braund $(1996,77)$.

${ }^{32}$ In Juvenal's case, J.D.Duff talks, for example, about "some rich man who lends his house and gardens $\langle\ldots\rangle$ for the purpose of recitations" (Duff 1957, 117).

33 Friedlaender 1886, 1, 200. Friedlaender 1895, 132.

${ }^{34}$ E. Groag thinks that he is the addressee of Martial's epigram (Groag 1899, 6, 1782). See also: Friedlaender $(1886,1,200)$ and $(1895,132)$; Morton Braund $(1996,77)$.

${ }^{35}$ Groag (Ibid.). J.E. B. Mayor is wrong assuming that he was also related to M.Cornelius Fronto (Mayor 1893, 1, 92).

${ }^{36}$ Friedlaender $(1886,1,200)$ and $(1895,132)$.

37 Haslink 1975, 2, 617-618.

385,$15 ; 7,12,22 ; 12,10 ; 19,2$.

39 Marsili 1957, 175; Maier 1991, 197-198.

40 "On peut être agronome sans être gastronome" (André 1965, 186).

${ }^{41}$ Dio 69, 18, 3.

${ }^{42}$ Eum. Pan. Lat. 8 (5), 14. 
brother Lucius Verus ${ }^{43}$. D. Vehling was the first to discuss M. Cornelius Fronto in connection with Apicius ${ }^{44}$. As was said above, the scholar attributes both pullus Frontonianus and Frontinianum porcellum to one person and sees as possible candidates either Julius Fronto who was praetor urbanus under Vitellius in 69 or Cornelius Fronto. Much later, in 2001, J.Edwards came up with a similar idea, having in mind the famous orator (though with a question mark $)^{45}$. His discussion of titles referring to regions in Apicius is very convincing and perfectly balanced; at the same time, the way he attributes recipes to certain people seems to me a bit simplistic and rash. It is hardly provable, for example, that patella Lucretiana $(4,2,25)$ was named after poet Lucretius ${ }^{46}$ and porcellum Celsinianum (8, 7, 12) after A. Cornelius Celsus, the author of medical texts ${ }^{47}$.

Nevertheless, I will try to find out whether attempts to associate M. Cornelius Fronto with pullus Frontonianus might have any ground. We have already seen that recipes named after certain people are not numerous in the "De re coquinaria", which means that eponyms should have been famous in one way or another. As to M. Cornelius Fronto, he definitely was a person of a very high rank, consul, and a member of the intimate circle both of the emperor Antoninus Pius and later that of Marcus Aurelius. Apart from his status and close connections at Court, he was also a man of substance: it is enough to mention, for example, that he was the owner of the villa and gardens of Maecenas that had previously belonged to the emperor Augustus. Being a highly educated and wealthy man, he made his house the center of an elite community, which is called by Fronto contubernium ${ }^{48}$ ('a band', 'crew', or 'brotherhood'), and he speaks of them not as 'pupils' (discipuli) but as his 'followers' (sectatores) or 'fellows' (contubernales) $)^{49}$. Aulus Gellius who was born one generation after Fronto $^{50}$ and had a chance to participate in the talks of the "sociabilité savante" ${ }^{51}$ to a certain extent reproduces the atmosphere of Fronto's house in the "Attic Nights" (NA 2, 26 etc.). He adores the intellectual atmosphere of these meetings, of course ${ }^{52}$, but one cannot assume that Fronto and his guests conversed and disputed on an empty stomach.

What place does food and gourmandize occupy in Fronto's letters? One should say that references to them are not numerous, which means that the orator and his correspondents were obviously not obsessed with gastronomic issues. A rare example when Fronto does talk about eating can be found in a letter addressed to Marcus Aurelius, which presumably dates from 148 C. E. ${ }^{53}$ but refers to an earlier period when Fronto was not yet his teacher ${ }^{54}$. Fronto confesses to his student that at that time he sometimes even reproached

${ }^{43}$ This is also mentioned in the inscription, which dates from 199 C. E. and is dedicated to Fronto's greatgrandson: "M. Aufidio Frontoni pronepoti M.Corneli Frontonis oratoris, consulis, magistri imperatorum Luci et Antonini <...>" (Corpus inscriptionum Latinarum 11, $6334=$ Dessau 1, 1129).

44 Vehling 1936, 196.

45 Edwards 2001, 261.

46 Ibid.

47 Ibid. For other interpretations of this dish see: Marsili 1957, 189; André 1965, 201.

48 Ad amic. I, 9. The numeration follows that of the edition: Hout van den, 1988.

49 Ad amic. I, 3, 2; Ad Ant. Pium 10, 1, etc. On Fronto's contubernium see: Johnson 2010, 137-156; Richlin 2011, 98-99.

50 According to L. Holford-Strevens, between 125 and 128 C. E. (Holford-Strevens 1988, 12).

${ }^{51}$ Jacob 2005, 3, 507-530.

52 At the same time, Gellius was capable of making realistic observations, such as mentioning of the fact that Fronto suffered from painful feet during one such visit $(19,10,1)$.

${ }^{53}$ Hout van den 1999, 180.

${ }^{54}$ Ibid. 183. 
Marcus with neglect of high life (?) when the future emperor was reading books at the theatre or at public feasts (Ad Marc. Caes. 4, 12, 5 - in theatro tu libros vel in convivio lectitabas). At the same time, Fronto mentions that at that time he himself did not avoid such occasions and meetings (Ibid.).

In general, moderate eating serves as the backdrop to Fronto's correspondence. As far as we know, the orator did not adopt this as a specific principle, but his poor health put severe restrictions on him, indigestion being only one of his problems ${ }^{55}$. In a letter to Marcus ${ }^{56}$, he complains, for example, of jaundice and losing his voice and adds that he could not eat during the day:

$\langle\ldots\rangle$ nisi post vesperam micularum minimum cum vino destillatum gluttivi. (Ad Marc. Caes. 5, 55, 1)

' $<\ldots>$ except that after nightfall I swallowed a few morsels of bread sprinkled with wine ${ }^{57}$.

Marcus Aurelius also was not a man of sound health and he was not fond of eating. In one of the letters addressed to his teacher ${ }^{58}$, he describes his extremely modest lunch (prandium) - in comparison to that of his messmates:

Quid me censes prandisse? Panis tantulum, cum conchim, caepas et maenas bene praegnatis

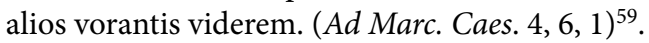

'What do you think I ate? A wee bit of bread, though I saw others devouring beans, onions, and herrings full of roe' ${ }^{60}$.

In another letter, the faithful disciple even declares that 'he would ten times prefer to garner the crop of his teacher's letters than that of all the Massic ${ }^{61}$ or Gauran vineyards ( $A d$ Marc. Caes. 4, 4, 2 - Nam decem partibus tuas litteras legere malim quam omnes Massicos aut Gauranos palmites). Marcus has in mind famous wine from the southern slopes of mons Massicus in central Italy ${ }^{62}$ and rare Gauran wine from "the volcanic hills near Puteoli in Campania" ${ }^{3}$. He plays with two meanings of the verb legere ('to read' and 'to collect') and prefers the metaphorical crop of Fronto's words to expensive wines.

Still, there is one example in the book of correspondence when food is praised, though in a quite peculiar manner. I am talking about two pairs of letters, which Fronto and Marcus exchanged, presumably, in 162 C.E. ${ }^{64}$ The text is preserved in the Ambrosian part of

\footnotetext{
${ }^{55}$ See for a profound discussion of Fronto's and Marcus' health: Scarborough 1969, 104-105; Whithehorne 1977, 36, 413-421; Freisenbruch 2003, passim; Freisenbruch 2007, 235-255.

${ }_{56}$ M. Van den Hout dates it roughly between 139 and 156 (Hout van den 1999, 212).

57 Haines, 1919, 1, 243. I accept a correction of M. Van den Hout "sprinkled with wine" for Haines' "soaked in wine" (Hout van den 1999, 213).

${ }^{58}$ It was written presumably between 141 and 143 C.E. (Hout van den 1999, 167).

59 Cf. Fronto Fer. Als. 4, 2.

60 Haines 1919, 1, 183.

61 The Vatican manuscript V (codex Vaticanus Latinus 5750 saec. V) reads Marsicum, but it does not make sense because Marsicum vinum was considered an austere and poor one (Athen. 1, 48 - Kaibel; cf. Mart. 13, 121). Modern editors adopt A. Kiessling's emendation Massicum (Hout van den 1988, 60).

62 Dalby 2003, 209.

63 Ibid. 158.

${ }^{64}$ Hout van den 1999, 509.
} 
Fronto's manuscript ${ }^{65}$, its title "De feriis Alsiensibus" being cited by an ancient scribe ${ }^{66}$. Marcus who had recently become the ruler was spending time at one of the imperial villas at Alsium on the coast of South Etruria. He ironically calls this four-day stay ${ }^{67}$ feriae 'holidays' (De Fer. Als. 1), but it is obvious that he had to work hard instead of enjoying the countryside. Fronto picks up his expression and advises his former pupil to take a rest, to read poetry ${ }^{68}$, to sleep, and to feast lavishly:

$<\mathrm{ut}>^{69}$ actutum inde balneas peteres, corpus ad sudorem uberem commoveres, convivium deinde regium agitares concheis omnium generum, Plautino "piscatu hamatili, ut ille ait, et saxatili'p70, altilibus veterum saginarum, matteis pomis bellariis crustulis vinis felicibus calicibus perlucidis sine delatoria nota (De Fer. Als. 3, 1)

'Anon you would be off from there to the baths, make yourself sweat profusely, then discuss a royal banquet with shellfish of all kinds, a Plautine catch hook-taken, rock-haunting, as he says, capons long fed fat, delicacies, fruit, sweets, confectionery, felicitous wines, translucent cups with no informer's brand ${ }^{771}$.

It is obvious that Fronto jokingly recommends things that are hardly possible for Marcus: the emperor is too busy to relax; insomnia has been a torment to him since his youth $^{72}$. It is only reading poetry that might be acceptable for Marcus in spite of pressure of work ${ }^{73}$. As to the praise of convivium regium, one can observe that it is deeply rooted in literature and literary polemics. On the one hand, Fronto, a champion of archaistic tastes, does not miss a chance to quote Plautus, one of his favorite ancient poets ${ }^{74}$. On the other, - and this seems also to be very important - he wants to ridicule the style of Seneca the Younger:

Ut homo ego multum facundus et Senecae Annaei sectator Faustiana ${ }^{75}$ vina de Sullae Fausti cognomento 'felicia' appello; calicem vero 'sine delatoria nota' cum dico, sine puncto dico. Neque enim me decet, qui sim tam homo doctus, volgi verbis Falernum vinum aut calicem acentetum appellare (De Fer. Als. 3, 2).

'I, as a man greatly eloquent and a disciple of Annaeus Seneca, call Faustian wines felicitous wines from Faustus Sulla's title; moreover when I speak of a cup without an informer's brand, I mean a cup without a spot. For it does not become a man so learned as I am to speak in everyday terms of Falernian wine or a flawless cup ${ }^{76}$.

${ }^{65}$ Codex Ambrosianus E 147 saec. V.

${ }^{66}$ Legi M. Frontonis De feriis Als<i>ensibus (De Fer. Als. 4, 2). The title's idea must have come from the first words of Marcus' letter, which opens the selection: Ferias apud Alsium $<\ldots>$ (De Fer. Als. 1).

67 De Fer. Als. 3, 1.

${ }^{68}$ Ibid. Fronto recommends reading Plautus, Accius, and Lucretius.

${ }^{69}$ From the preceding.

70 This is a quotation from Plautus: post id piscatum hamatilem et saxatilem aggredimur (Rud. 299).

71 Haines 1919, $2,7$.

72 On Marcus' sleeplessness see, for example: Ad Marc. Caes. 2, 8, 3; Ad Marc. Caes. 3, 22, 2; Ad Marc. Caes. 5, 1. He even composes a humourous letter pro insomnia (Ad Marc. Caes. 1, 4).

${ }^{73}$ Cf. Ad Ant. Imp. 4, 1, 3. In the letter written in 161 C. E. (Hout van den 1999, 259) Marcus, already an emperor, asks Fronto to send him excerpts from Lucretius and Ennius.

${ }^{74}$ Fronto also quotes Plautus in the text below (De Fer. Als. 3, 2). L. Ehrenthal (1881, 37, n. 77) believes that veterum saginarum in our passage might be a citation from an unknown archaic poet.

${ }^{75}$ Wine from the Falernian region in Italy (Plin. $\left.N H ~ 14,62,5\right)$.

${ }^{76}$ Haines 2, 7. 
In the correspondence, Fronto shares with Marcus Aurelius his love for pre-classical Latin authors, including prose writers prior to Cicero and poets before Virgil. At the same time, he does not explicitly criticize Latin literature of the classical period; instead, he simply omits certain names from his discussion. In such a way, he never mentions or quotes Virgil. Another outstanding poet, Horace, is referred to only once: Fronto calls him, at least, 'remarkable' (poeta memorabilis), but then he jokingly says that their connection is 'through Maecenas' and his (Fronto's) 'gardens of Maecenas' (Ad Marc. Caes. II, 2, 5) '7 $^{77}$ having in mind the villa at the Esquiline Hill ${ }^{78}$.

It is worth mentioning that Fronto and Quintilian, the author of the most extensive literary canon of antiquity, have similar attitudes towards Cicero and Seneca, two major literary figures of the period. They both speak very highly of Cicero, though Fronto's account is more varied and mixed ${ }^{79}$ in comparison to a pure panegyric in Quintilian ${ }^{80}$. Both rhetoricians find limitations and imperfections in the style of Seneca the Younger. (Quint. Inst. 10, 125-131; Fronto De orat. 2-3; De Fer. Als. 3, 2), but this does not necessarily mean, of course, that Fronto was influenced by Quintilian's judgment. Seneca was a symbol of a postclassical trend ${ }^{81}$ in Latin, and Quintilian, who promoted neo-Ciceronianism, could not approve of him. At the same time, we see that he leaves his account of Seneca until last and the discussion is "the second longest devoted to a single author" ${ }^{82}$. This can be explained by the fact that Seneca was a major figure of his time and a very attractive one for students of oratory. This is the reason why Quintilian could not ignore his influence, and he chose to discuss not only Seneca's stylistic defects but also his merits. In the second century, Seneca's impact was not as strong as in the first century, nevertheless Fronto still realizes its danger for Marcus and warns of the drawbacks of this "effeminate" style: he talks about 'the soft plums of Seneca, which produce fever'83 (Senecae mollibus et febriculosis prunuleis - De orat. 2). Though Fronto acknowledges occasional lucky expressions in Seneca (De orat. 3), he criticizes his writings for saying the same thing over and over again (De orat. 4$)^{84}$.

In the passage cited above, Fronto sarcastically calls himself 'Seneca's follower' (De Fer. Als. 3, 2) and mocks his style by saying that he cannot simply speak of Falernian wine but names it 'felicitous' (felix) after cognomentum of Sulla Faustus ${ }^{85}$. In a similar way, he talks about 'a cup without an informer's brand' instead of using a technical term acentetus ${ }^{86}$

${ }_{77}$ Fronto's praise of Horace in Ad Marc. Caes. II, 2, 5 is taken seriously and over exaggerated by J. F. D’Alton (1962, 321).

78 The villa was once owned by Maecenas, then by the emperor Augustus, and later by M. Cornelius Fronto. It remained a property of his descendants at least until the end of the third century (Corpus inscriptionum Latinarum 15, 7398).

${ }_{79}$ For the preference of Cicero's letters over his speeches, see: Ad Ant. Imp. III, 8, 2. In Ad Marc. Caes. IV, 4, 3 Fronto states Cicero was not always careful about his choice of words.

${ }^{80}$ Cicero receives in Quintilian the longest discussion among all Roman and Greek writers (Inst. 10, 105 ss.).

81 Dominik 1997, 74.

82 Ibid.

83 Brock 1911, 307.

${ }^{84}$ A poet M. Annaeus Lucanus, Seneca's nephew, is charged with the same faults (De orat. 6).

85 It is not clear which Sulla Fronto has in mind. Dictator L. Cornelius Sulla had an agnomen Felix but not Faustus. M. Van den Hout believes it more probable that Fronto is talking about Sulla's son or grandson who were called Fausti $(1999,501)$. In this case, it seems that he should have translated faustus as felix (because these descendants of Sulla did not bear an agnomen Felix).

${ }^{86}$ Cf. Plin. NH 37, 28. 
for flawless glass. Neither of these examples is preserved in the corpus of Seneca's writings, as we have it today; so it is impossible to say whether Fronto quotes his literary antagonist or parodies his manner. Whatever the answer may be, it seems that Fronto introduced a passage in praise of gourmandize not for the sake of the food, but in order to set off his taste for old Latin authors against his dislike of Seneca's mannerist style.

To conclude, it seems that there are no compelling arguments to attribute with certainty pullus Frontonianus from the cookbook "De re coquinaria" (Apic. 6, 8, 12) to any of the Frontones discussed above. In the case of M. Cornelius Fronto, his fame and opulence might give grounds for calling the dish after him. At the same time, I have tried to show that the internal logic of his correspondence is in conflict with such a possibility because the only praise of foodstuffs is tinged with rhetorical admonition and irony. Therefore, the teacher of Marcus Aurelius can be no more than one of the number of theoretical eponyms of chicken à la Fronto.

\section{References}

André, J. (éd.) Apicius L’art culinaire. Paris, Klincksieck, 1965.

Brock, M. D. Studies in Fronto and His Age, Cambridge, Cambridge University Press, 1911.

D’Alton, J.F. Roman Literary Criticism: A Study in Tendencies, New York, Russell \& Russell, $1962^{2}$.

Dalby, A. Food in the Ancient World from A to Z. London, Routledge, 2003.

Dessau, H. (ed.) Inscriptiones Latinae selectae. Chicago, Ares Publishers, 1979, 1 (=1892).

Dominik, W. J. The Style is the Man: Seneca, Tacitus and Quintilian's Canon, in: Dominik, W. J. (ed.) Roman Eloquence. Rhetoric in Society and Literature, London, Routledge, 1997, 42-57.

Duff, J.D. (ed.) D. Iunii Iuvenalis Saturae XIV. Cambridge, Cambridge University Press, 1957.

Edwards, J. Philology and Cuisine in De re coquinaria, The American Journal of Philology, 2001, 122 (2), 255-263.

Ehrenthal, L.C. W. Quaestiones Frontonianae. Diss. Königsberg, Hartung, 1881.

Faas, P., Around the Roman Table. London, Macmillan, 2003. Available at: https://books.google.ru (3.5.2016).

Freisenbruch, A. The Correspondence of Marcus Cornelius Fronto. Diss., Cambridge, 2003.

Freisenbruch, A. Back to Fronto: Doctor and Patient in His Correspondence with an emperor, in: Morello, R., Morrison, A. D. (eds.) Ancient Letters: Classical and Late Antique Epistolography, Oxford, Oxford University Press, 2007, 235-255.

Friedlaender, L. (Hrsg.) M. Valerii Martialis Epigrammaton libri. Leipzig, Hirzel, 1886, 1.

Friedlaender, L. (Hrsg.) D. Iunii Iuvenalis Saturarum libri V. Leipzig, Hirzel, 1895.

Fuhrmann, M., Caelius, in: W Ziegler, K., Sontheimer W. (Hgg.), Der kleine Pauly: Lexikon der Antike, . München, A. Druchenmüller Verlag, 1974, 1, 984.

Grigor'eva, A. A. Drevnerimskaia kulinarnaia leksika. Problema terminologii: Na materiale tekstov apitsievskogo korpusa. Avtoreferat dissertatsii na soiskanie uchenoi stepeni kandidata filologicheskikh nauk. Moskva, Izdatelstvo MGU, 2000 [Grigor'eva, A. A. Roman Culinary Vocabulary: Terminology Issues (Based on Texts Ascribed to Apicius). Diss. Summary. Moscow, Moscow University Press, 2000] (in Russian).

Groag, E., Catius 4, in: Pauly, A. F. von, Wissowa G. (Hgg.) Paulys Realencyclopädie der classischen Altertumswissenschaft, Stuttgart, Metzlerscher Verlag, 1899, 6, 1782.

Groag, E. et al. Fronto, in: Pauly, A. F. von, Wissowa G. (Hgg.), Paulys Realencyclopädie der classischen Altertumswissenschaft, Stuttgart, Metzlerscher Verlag, 1910, 13, 111-112.

Grocock, C., Grainger, S. (eds., transl.) Apicius: A Critical Edition with an Introduction and an English Translation of the Latin Recipe Text Apicius. London, Prospect Books, 2006.

Haines, C. R. (ed., transl.) The Correspondence of Marcus Cornelius Fronto with Marcus Aurelius Antoninus, Lucius Verus, Antoninus Pius, and Various Friends. Cambridge, Massachusetts, Harvard University Press, 1919, 1-2.

Haslink, R. Fronto, in: Ziegler, K., Sontheimer, W. (Hgg.) Der kleine Pauly: Lexicon der Antike, München, Druchenmüller Verlag, 1975, 2, 617-618.

Holford-Strevens, L. Aulus Gellius: An Antonine Scholar and his Achievement. Oxford, Oxford University Press, 1988. 
Hout van den, M. P. J. (ed.) M. Cornelii Frontonis Epistulae. Leipzig, Teubner, 1988.

Hout van den, M. P. J. A Commentary on the Letters of M. Cornelius Fronto. Leiden; Boston; Köln, Brill, 1999.

Jacob, C. La table et le cercle: Sociabilités savantes sous l'Empire romain, in: Annales, Histoire, Sciences Sociales, 2005, 3, 507-530.

Johnson, W. A. Readers and Reading Culture in the High Roman Empire: A Study of Elite Communities. Oxford, Oxford University Press, 2010.

Maier, R. (Hg., Übers.) Marcus Gavius Apicius De re coquinaria. Über die Kochkunst, Stuttgart, Philip Reclam jun., 1991.

Marsili, A. (ed.) Apicius De re coquinaria. Pisa, Colombo Cursi editore, 1957.

Mayor, J. E. B. (ed.) Thirteen Satires of Juvenal. London, Macmillan, $1893\left(=1872^{2}\right), 1,92$.

Milham, M.E. (ed.) Apicii decem libri qui dicuntur De re coquinaria et excerpta a Vinidario conscripta, Leipzig, Teubner, 1969.

Morton Braund, S. (ed.) Juvenal Satires Book I. Cambridge, Cambridge University Press, 1996.

Richlin, A. Old Boys: Teacher-Student Bonding in Roman Oratory, in: The Classical World, 2011, 105, 1, 91-107.

Scarborough, J., Roman Medicine, London, Thames and Hudson, 1969.

Schuch, Chr. T. (Hg.) Apici Caeli De re coquinaria libri decem. Heidelberg, Carol Winter, 1867.

Vehling, J.D. (ed., transl.) Apicius: Cookery and Dining in the Imperial Rome. Chicago, Hill, 1936 (=New York, Dover Publications; London, Constable, 1977).

Vollmer, F. Studien zu dem römischen Kochbuche von Apicius, in: Sitzungsberichte der Bayerischen Akademie der Wissenschaften, Philosophisch-Philologische und Historische Klasse, 1920, 6, 1-46.

Whithehorne, J.E. G. Was Marcus Aurelius a Hypohondric? in: Latomus, 1977, 36, 413-421.

For citation: Budaragina O. V. Chicken à la Fronto. Philologia Classica 2016, 11(1), 54-63.

DOI: $10.21638 / 11701 /$ spbu20.2016.105

\section{ЦЫПЛЕНОК À LA ФРОНТОН}

\section{Ольга Владимировна Бударагина}

В статье обсуждаются возможные эпонимы pullus Frontonianus, одного из рецептов приготовления цыпленка в приписывавшейся Апицию поварской книге "De re coquinaria" (Apic. 6, 8, 12). Атрибуция сталкивается с рядом трудностей, в числе которых неопределенность времени жизни Апиция и датировка корпуса, а также тот факт, что cognomen 'Fronto' не относился к определенному nomen gentilicium. В числе возможных претендентов рассматриваются адресат эпиграммы Марциала $(\mathrm{I}, 55,2)$, богатый патрон из сатиры Ювенала $(1,12)$, а также автор трудов по сельскому хозяйству, живший при императоре Септимии Севере. Отдельный раздел посвящен самому знаменитому из Фронтонов - М. Корнелию, воспитателю Марка Аврелия. Рассматриваются как внешние свидетельства, так и переписка самого Фронтона с целью взвесить возможность атрибуции ему названия блюда. Автор приходит к заключению, что отсутствуют неопровержимые факты, которые позволили бы с уверенностью приписать название блюда одному из исторических Фронтонов.

Ключевые слова: М. Корнелий Фронтон, pullus Frontonianus, Апиций, еда в античности, Марк Аврелий, Сенека Младший. 